\title{
Design and Manufacture of Wireless Monitoring System of Photovoltaic Generation Employing Raspberry PI 3
}

\author{
Krismadinata $^{1 *}$, Puja Kusuma ${ }^{2)}$, and Yahfizham ${ }^{3)}$ \\ 1,2) Department of Electrical Engineering, Faculty of Engineering Universitas Negeri Padang, Indonesia \\ ${ }^{2)}$ Department of Mathematic Education, Universitas Islam Negeri Sumatera Utara, Indonesia \\ Corresponding Email: *) krisma@ft.unp.ac.id
}

\begin{abstract}
This paper recounts design and development the real-time and wireless monitoring systems to observed the characteristics and performanced of the solar photovoltaic (pv) energy generation. The monitoring systems designed used the Raspberry Pi 3 as the data processing center, the voltage divider as the voltage sensor, ACS712 as the current sensor, DHT as the temperature sensor, and BH1750 as the solar irradiation sensor. The measurements of the pv generation characteristics are carried out all the time in real time. The monitoring systems developed has calibrated with standard measuring instruments. The measurement data has processed, sent and stored in the database via the internet. The MySQL database with single user interface using the Web-based programming language has employed. This research has proven that the system designed to functioning properly and correctly to achieve the objectived. The novelty of these project are the pv wireless monitoring systems techniques with the simple device resources, capable of showing maximum performanced.
\end{abstract}

Keywords: Wireless Monitoring System, Photovoltaic generation, Raspberry PI3, irradition, temperature

\section{INTRODUCTION}

Today, the electric energy has needed over the daily activities. Utilizing the solar photovoltaic (pv) energy (renewable energy) is a smart way [1] to obtain low-cost effective electricity potential [2]. The renewable energy has availabled any time, so that the problem of shortage of electrical energy supply can be overcome. The solar power plant systems (renewable energy systems) of the devices capable to converted the solar energy to electric energy, which are always availabled.

In Indonesia, according to [3] the solar energy en estimated 12 hours per day with it high intensity of 4.8 $\mathrm{kWH}$ per $\mathrm{m} 2$ per day and it effective illumination time of 5 hours per day, located on the equator has been a favorable geographical to the renewable energy [4].

A solar energy potential has not been maximized when it rains or the weather is cloudy to conversion from it per day and any times [5], which implies the treatment that it must be stored and utilized as much as possible during normal climatic situations in order to produces maximum output power [6-8]. The weather situation and condition that must be considered are related to the temperature of the solar energy which it intensity decreases.

According to [9-11], the performance efficiency of monocrystalline and polycrystalline the solar irradiance drops dramatically when temperature changes take place. Working the characteristics of the solar panel systems are influenced by exposure to sunlight and solar heat. When there is less light exposure on the surface of the solar panel and the heat around the solar panel is excess, it will reduce the output power of the solar panel [12-14].

The intensity of irradiation and the temperature for the solar pv module affects the output power of the solar pv module, the greater the irradiation received by the solar pv module energy, the greater the solar energy produced [15], on the contrary if the greater the temperature of the solar pv module, the less solar energy is produced [16]. Another parameter to the solar pv module, considered is the ambient temperature [17]. These process of course requires the systems that can monitor the pv modules working properly.

A monitoring system is defined as an activity cycle that includes the collection, review, reporting, and action of information on a process being implemented [18-20]. Monitoring the solar power plant systems are necessary to obtain information on plant performance and sustainability of installed generating units in order to provided useful the information and optimal results [21].

Monitoring the solar power plant systems are still done directly and will take to long time and inefficient [22]. These requires optimal design [23]. Monitoring the solar power plant systems in addition to need it to be optimally designed to be able to access units located in different locations are also designed to be accessible to operators, electrical engineering personnel, or interested parties to monitor in though the real time and the online in a long distance [24].

The various types of the wireless monitoring systems that used with the Arduino UNO for microcontrollers as brains to process measurement the data have been widely performed [25-29]. The Arduino UNO microcontrollers required additional module and additional programming for connection to the internet which makes tool design more complicated and a long time counting processed [30].

The tools of the wireless monitoring the solar power 
plant systems using Raspberry Pi have been also created by [31][32], based on the Internet of Things (IoT) and can be accessed through the website. But the weakness of the tools are that the website address can not fixed because it uses a DHCP Hostname IP, which means the website address will be change every Raspberry Pi turned off [3436]. This will be result in iteration of the activity for each access, and then the website page activity process lacked maximum because it must first see the address of the website page to be opened [37][38].

Using the Raspberry $\mathrm{Pi}$ as a single board computer is easy to use because it can be directly connected to the internet using Wi-Fi or LAN cables without additional modules [39]. Programming for the configuration of the website page, and the database is done inside the Raspberry $\mathrm{Pi}$, by providing a Node.js interface and a single band connection network [40] but the advantage of the raspberry $\mathrm{Pi} 3$, is it self that the frequency of the connection has been dual band and has the added feature of better temperature control (not easy heat).

The ultimate goal of this article has been to develop an improved and explained version that the wireless monitoring system using Raspberry $\mathrm{Pi} 3$ as the data processing center, the voltage divider as the voltage sensor, the ACS712 as the current sensor, the DHT as the temperature sensor, and the BH1750 as the solar energy illumination sensor. The measurements of the solar photovoltaic (pv) energy generation characteristics has been performed all the time in the online real time systems. The wireless monitoring systems developed has been calibrated with standard measuring instruments. The measurement data has been processed, transmitted and stored in the databases over the IoT. The MySQL database with user interface using web based system programming language. This research proves that the designed system works properly and correctly to achieve its goals. The novelty of these project are the techniques of the photovoltaic wireless monitoring systems with the simple device resources, capable of demonstrating maximum performance.

\section{METHODOLOGY}

\section{A. Design Model Monitoring System}

Monitoring of the solar pv modules is carried out with sensors that detect the amount of electricity and the amount of physics from the solar power plant systems to Raspberry Pi 3. The measurement data is stored on the database systems and the web-based interfaces display the required information. The information provided is accessed through the internet anywhere and anytime. The various electronic components has been used in designed the monitoring systems such as the ACS712, the DC voltage sensor, the BH1750 irradiation sensor, the DHT11 and the DHT22 sensors.

The design model of the solar power plant systems performance can be seen in Figure 1. The design model of the solar power plant systems that the Raspberry Pi 3 has been used as the main controller. The data has been processed from voltage, current, temperature, and solar irradiation. The data has been sensed by various sensors such as the ACS712 current sensor, voltage divider frame as the voltage sensor, the BH1750 irradiation sensor, the DHT11 and the DHT22 sensor as temperature and humidity sensor.

Data from the sensors will be processed by the ADC MCP3008 and then Raspberry Pi 3 with a 10-minute snapshot time. From Raspberry Pi 3, the data sent to the database which is then to displayed to the website monitoring. For websites that have been programmed with HTML+PHP the data can be seen in the form of tables and graphs.

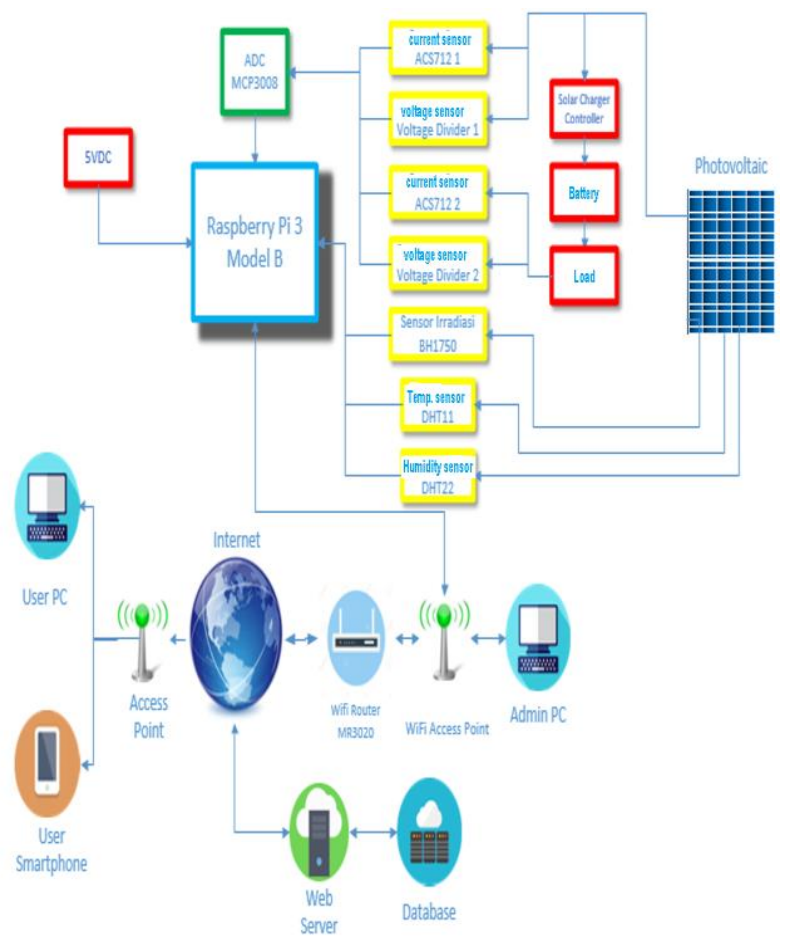

Figure 1. Design Model Monitoring System

Users with personal computers or smart phones will request services to the system via access point that serves as an agent or connection of the device through the router in order to share access to the internet network by first requesting an access key to the system administrator (PC admin).

The web server that serves to host the data and the display data results monitoring to browser and provide requests in the form of the web pages or Hyper Text Markup Language (HTML) documents. The domain page addresses serve to make it easier for users to access the web page identifiers. The database system serves as a place to store monitoring data that is located in the web server application system as a user interface.

\section{B. Flow Chart Monitoring System}

The flow chart wireless monitoring system has been designed, can be seen in Figure 2. The data management design via web begins with the initial display of the wireless monitoring systems. After the initial view of the website will go into the table view of the system data. After the data is obtained, the measurement result is 
obtained, the process of uploading the measurement data has been done by saving the data into the data storage system. After that the HTML+PHP program retrieves and displays the data in the form of tables and line graphs. (table not displayed)

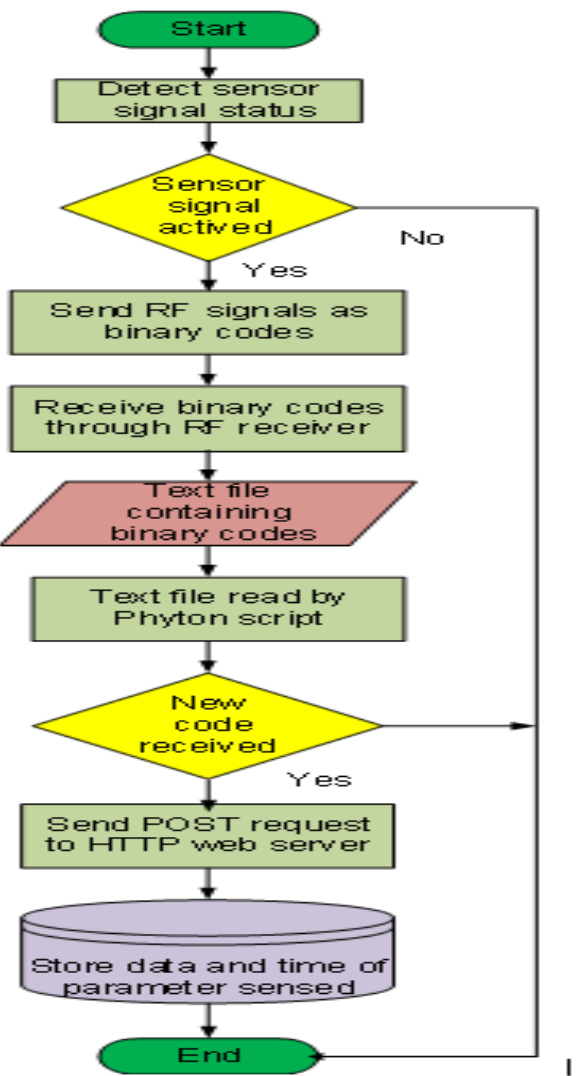

Figure 2. Flow Chart Monitoring System

The input data flow diagram of the designed of the wireless monitoring system via Raspberry Pi 3, starting with the start symbol. This means that the Raspberry Pi 3 gets a voltage supply and General-Purpose Input-Output (GPIO) pin initialization. This means that the Raspberry Pi 3 done to initialize the GPIO pin used. The program will be perform variable declarations, and then to set the Serial Peripheral Interface (SPI) to be able to received from the ADC data to sent and recived to the MCP3008, and configure the internet. After that proceed to the reading process of the existing sensors. This process has been a differenced for the temperature sensors because the temperature sensor has a digital output data, so it is able to be directly processed Raspberry Pi 3 . While the voltage sensor and the current sensor must be processed first by the MCP3008 as the ADC sensors, so that the output are the digital data.

\section{RESULTS AND DISCUSSION}

\section{A. Prototype Testing Results}

A prototype design of the wireless monitoring system proposed and performanced using the Raspberry Pi 3 can be seen in Figure 3.

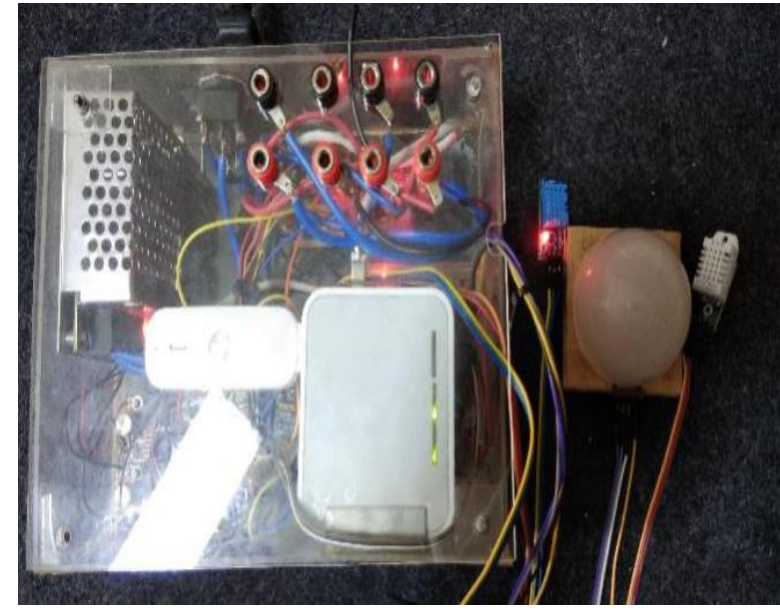

Figure 3. The Prototype of wireless monitoring system

The prototype consists of the Raspberry Pi 3, the power supply, the MCP3008, the voltage sensor, the ACS712 current sensor, the DHT11 and the DHT22 temperature sensor, the BH1750 solar irradiation sensor, the router, and the modem framed in an acrylic box measuring $20 \mathrm{~cm}$ $\times 16 \mathrm{~cm} \times 8 \mathrm{~cm}$. The DHT11 and the DHT22 temperature sensors and the BH1750 solar irradiation sensors are connected to 1-meter cable and are not placed in the box due to the placement of these sensors at the top and bottom of the solar module panels.

In Figure 4, seems like that the wireless monitoring systems test configuration with the prototype designed. A $50 \mathrm{Wp}$ solar cell module has been used as an the solar cell energy source; the solar cell energy charger controller has been used to extract maximmune power from the solar cell module, the battery has been used as the solar cell energy storage; the inverters are used to convert the amount of direct current into a source of alternating current; and 2 lamps are used as a source of electrical load.

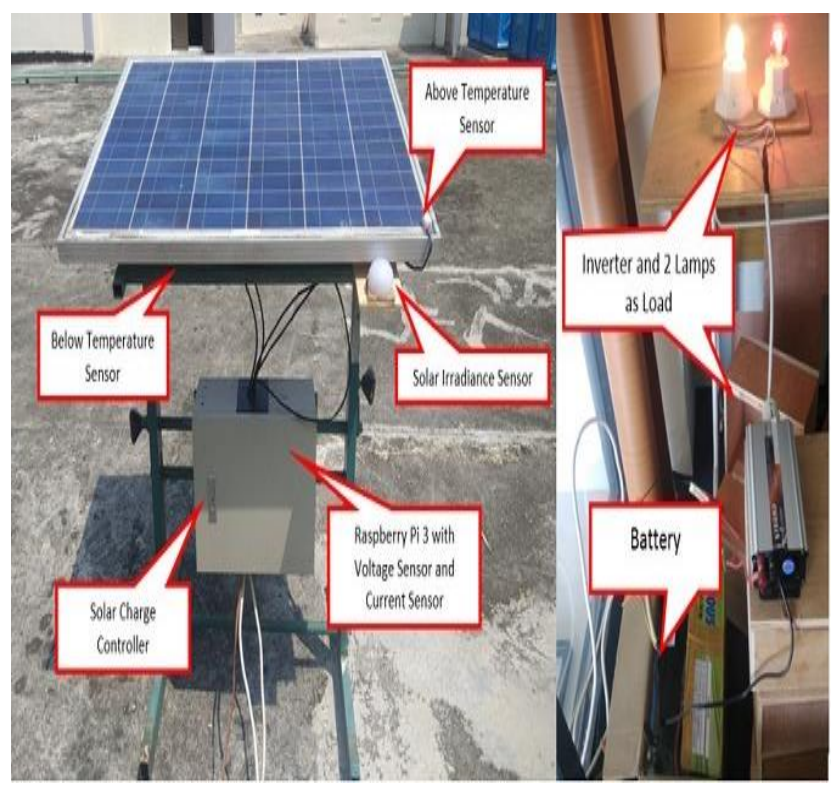

Figure 4. The Configuration of experiment setup test 
When all the circuits can work properly, and as expected, it will be obtained current, voltage, irradiation and temperature. The characteristic measurement data of the wireless monitoring systems that has been monitored from displayed through on the IoT seems like to website www.erc.unp.ac.id/monitoring.

The result of measuring wireless monitoring systems parameters well done with the data retrieval interval every 10 minutes by connecting the solar cell charger controller to the battery. The battery output has been connected with inverters and lamps as an electrical load. The surface temperature of the upper and lower solar cell modules has been sensed with sensors. The BH1750 sensor senses solar cell irradiation. The measurement was conducted on Saturday, May 16, 2020 at 09:00 AM to 03:00 PM, with 2 a load of 5 Watt lamps.

The effect of solar energy radiation on the solar cell module voltage well done with the data obtained from load voltage. Testing was conducted to determine the magnitude of the influence of solar energy irradiation on solar cell module voltage and load voltage.

In Figure 5, seems like the characterization of solar cell modules, especially the influence of solar irradiation on the voltage generated by solar cell modules. The highest value of the strong intensity of the solar energy beam occurred at $11.59 \mathrm{WIB}$ at $825.43 \mathrm{~W} / \mathrm{m} 2$, as well as the highest voltage raised by $13.35 \mathrm{~V}$, occurred at the same time. It can be known if the time is approaching noon or around 12:00WIB then the voltage and irradiation of sunlight obtained is higher. However, if the time passes 12:00WIB then the voltage and irradiation of sunlight will be decreased. The situation depends on the weather or climate in the area of the solar cell module being monitored.

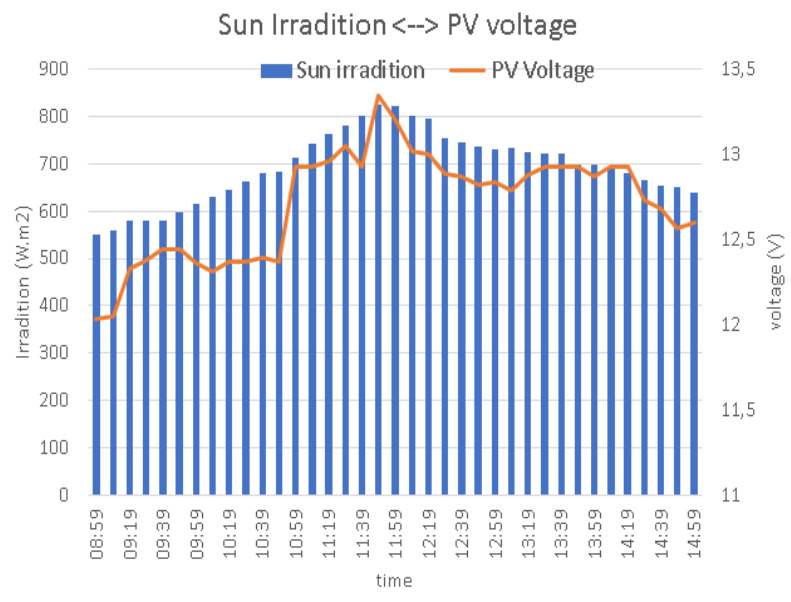

Figure 5. The irradiation and PV voltage

The effect of changes in the intensity of sunlight hitting solar cell modules to changes in load voltage can be seen in Figure 6. Load voltage does not change much when solar energy light intensity changes. The largest load voltage occurs at a voltage of 12.27 volt with solar energy light irradiation of $825.43 \mathrm{~W} / \mathrm{m} 2$.

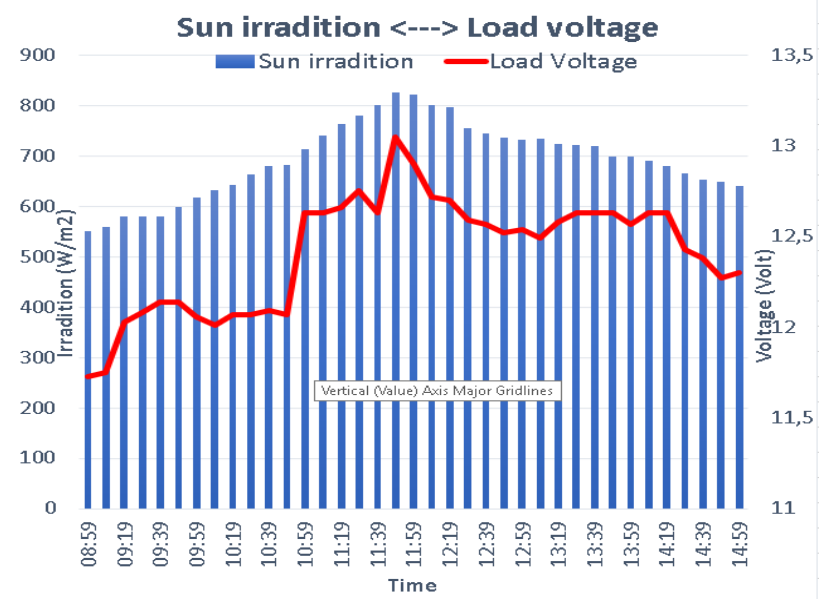

Figure 6. The irradiation and load voltage

In Figures 7 and 8 can be seen the influence of changes in the intensity of solar energy light that hit the surface of the solar cell module against the load currents assembled at the source of the solar cell module. The largest solar cell module current occurs when the intensity of solar energy light is also large as well. This highest value occurred at 11.59 WIB.

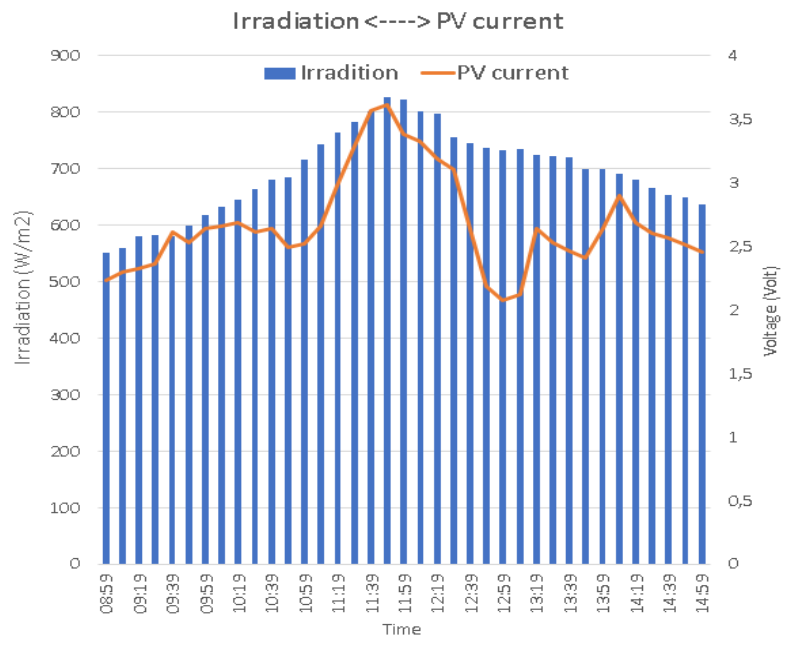

Figure 7. The irradiation and PV current

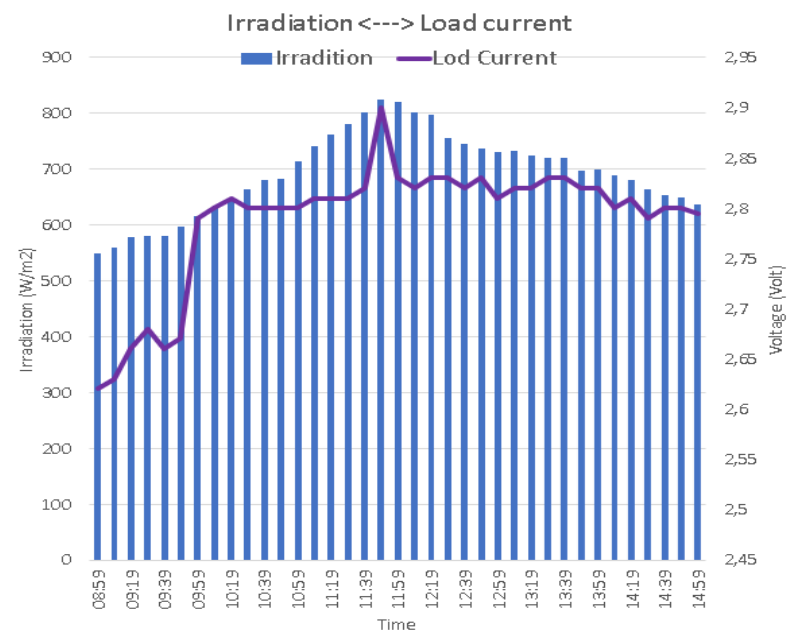

Figure 8. The irradiation and load voltage 


\section{B. Software Analysis}

The results of the analysis of the software using the application Raspberry PI 3 has been done with a laptop. The default operating system of Raspberry PI 3 is Raspbian Stretch. The hardware communication systems with software require configuration techniques between the devices. The display of the interface of the Raspberry PI 3 configuration as seen by Figure 9 .

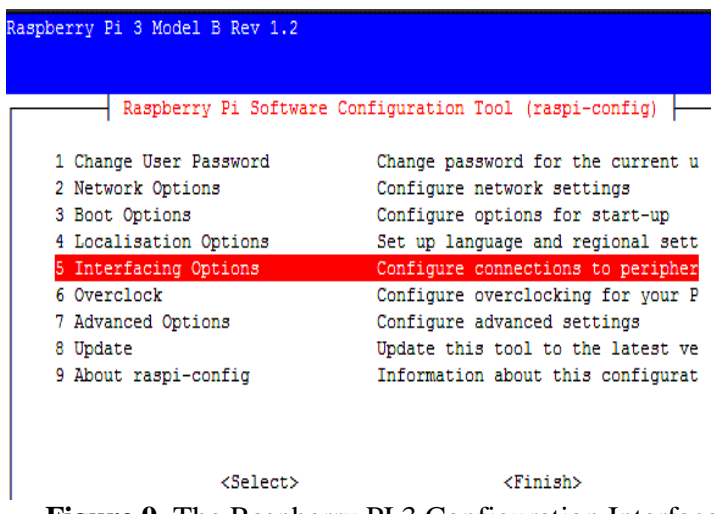

Figure 9. The Raspberry PI 3 Configuration Interface

The MySQL database configuration which is the free software needed to manage the data obtained from the input hardware and display the results on the web-based user interface. The results of the MySQL database configuration has been done with direct access to the portal page (web site) i.e. https://remotemysql.com. In the database application, has two tables, the first is the monitor table, and the second is the user table. The monitor table is required to store data of all sensors and user table to store user name and keyword data. (table not displayed)

\section{CONCLUSIONS}

Based on the test results of all the hardware, software, and analyzing the characteristics of the wireless monitoring the solar power plant systems designed using Raspberry $\mathrm{Pi} 3$, concluded that the systems has been successful and run properly to processed the data voltage, current, temperature, and solar energy irradiation. Monitoring system programming software can interact with the hardware well according to the design because it can retrieve data from sensors, send, and store the data to the database storage, and display it to the website as useful information, so that it can be monitored anytime and anywhere.

\section{ACKNOWLEDGMENT}

We would like to thank all parties who helped on this research, especially from the Universitas Negeri Padang who have allowed the use of IP address or domain as a user interface access page.

\section{REFERENCES}

[1] T. Hu, M. Zheng, J. Tan, L. Zhu, and W. Miao, "Intelligent photovoltaic monitoring based on solar irradiance big data and wireless sensor networks," Ad Hoc Networks, pp. 111, 2015.

[2] A. Brajamusthi, S. R. I. Utami, and D. Sodiq, "PLTS TransformerlessTegangan $20 \mathrm{kV}$ menggunakan Cascaded H-Bridge Multilevel Inverter," ELKOMIKA, vol. 6, no. 1, pp. 16-34, 2018.

[3] S. Nahela, et al., "Analisa Unjuk Kerja Grid Tied Inverter Terhadap Pengaruh Radiasi Matahari dan Temperatur Pv pada PLTS On-Grid,"ELKHA, J. Tek. Elektro, vol. 11, no. 2, pp. 60-65, 2019.

[4] Y. Yandri, "Photovoltaic-Power Water Pumping System," ELKHA, vol. 1, no. 3, pp. 27-33, 2009.

[5] F. Hidayat, D. Rusirawan, I. Rachmadi, and F. Tanjung, "EvaluasiKinerja PLTS 1000 Wp di Itenas Bandung," ELKOMIKA, vol. 7, no. 1, pp. 195-208, 2019.

[6] R. Dabouet al., "Monitoring and performance analysis of grid connected photovoltaic under different climatic conditions in south Algeria," Energy Convers. Manag., vol. 130, pp. 200-206, 2016.

[7] P. Guerriero, F. Di Napoli, G. Vallone, V. Alessandro, and S. Daliento, "Monitoring and Diagnostics of PV Plants by a Wireless Self-Powered Sensor for Individual Panels," IEEE Journal of Photovoltaic, vol. 6, no. 1, pp. 286-294, 2016.

[8] S. Moon, et al., "A New Low-Cost Centralized MPPT Controller System for Multiply Distributed Photovoltaic Power Conditioning Modules," IEEE Transactions on Smart Grid, pp. 1-10, 2015.

[9] D. A. Quansah and M. S. Adaramola, "ScienceDirect Comparative study of performance degradation in polyand mono-crystalline-Si solar PV modules deployed in different applications," Int. J. Hydrogen Energy, pp. 1-18, 2018.

[10] R. A. Rahman and H. Putranto, "Performance Comparative Analysis of Monocrystalline and Polycrystalline Single Diode Solar Panel Models using the Five Parameters Method,"Frontier Energy System and Power Engineering, vol. 1, no. 1, pp. 14-19, 2019.

[11] P. Dingus, J. Garnett, S. Wang, and C. Chong, "Solar Energy Materials and Solar Cells Low temperature growth and extrinsic doping of mono-crystalline and polycrystalline..," Sol. Energy Mater. Sol. Cells, vol. 189, pp. 118-124, 2019.

[12] M. Obeng, S. Gyam, N. Sarfo, and A. T. Kabo-bah, "Technical and economic feasibility of a $50 \mathrm{MW}$ gridconnected solar PV at UENR Nsoatre Campus," Journal of Cleaner Production, pp. 1-13, 2019.

[13] A. D. Adam and G. Apaydin, "Grid connected solar photovoltaic system as a tool for green house gas emission reduction in Turkey," Renew. Sustain. Energy Rev., vol. 53, pp. 1086-1091, 2016.

[14] H. Shahid, M. Kamran, Z. Mehmood, M. Yasir, M. Mudassar, and K. Haider, "Implementation of the novel temperature controller and incremental conductance MPPT algorithm for indoor photovoltaic system," Sol. Energy, vol. 163, no. January, pp. 235-242, 2018.

[15] D. Rusirawan and I. Farkas, "Identification of model parameters of the photovoltaic solar cells," Energy Procedia, vol. 57, pp. 39-46, 2014.

[16] A. Triki-lahiani, A. B. Abdelghani, and I. Slama- 
belkhodja, "Fault detection and monitoring systems for photovoltaic installations: A review," Renew. Sustain. Energy Rev., pp. 1-13, 2017.

[17] S. Benlebna, N. Manoj, and A. Tahri, "ScienceDirect Data acquisition system : On the solar photovoltaic module and weather parameters monitoring," Procedia Comput. Sci., vol. 132, pp. 873-879, 2018.

[18] M. Hosenuzzaman, N. A. Rahim, J. Selvaraj, and M. Hasanuzzaman, "Global prospects, progress, policies, and environmental impact of solar photovoltaic power generation," Renew. Sustain. Energy Rev., vol. 41, pp. 284-297, 2015.

[19] S. Dalientoet al., "Monitoring, Diagnosis, and Power Forecasting for Photovoltaic Fields: A Review," International Journal of Photoenergy, vol. 2017, pp. 1-13, 2017.

[20] S. R. I. Utami, "Optimal Design Of Renewable Energy System using Genetic Algorithm Case Study In Parangtritis," ELKOMIKA, vol. 4, no. 2, pp. 148-159, 2016.

[21] M. N. Akram and S. Lotfifard, "Modeling and Health Monitoring of DC Side of Photovoltaic Array," IEEE Transactions on Sustainable Enegy, pp. 1-9, 2015.

[22] M. Fuentes, et al., "Solar Energy Materials \& Solar Cells Design of an accurate, low-cost autonomous data logger for PV system monitoring using Arduino ${ }^{\mathrm{TM}}$ that complies with IEC standards," Sol. Energy Mater. Sol. Cells, vol. 130, pp. 529-543, 2014.

[23] O. B. Belghith., and L. Sbita,"Remote GSM module monitoring and Photovoltaic System control," First International Conference on Green Energy ICGE 2014, pp. 188-192, 2014.

[24] P. Putu, T. Winata, I. W. A. Wijaya, and I. M. Suartika, "RancangBangunSistem Monitoring Output dan Pencatatan Data pada Panel Surya Berbasis Mikrokontroler Arduino,"E-Journal SPEKTRUM, vol. 3, no. 1, pp. 1-6, 2016.

[25] R. R. A. Siregar and N. Wardana, "Sistem Monitoring Kinerja Panel Listrik Tenaga Surya Menggunakan Arduino UNO," JETri, vol. 14, pp. 81-100, 2017.

[26] W. H. Al-sawalmeh and M. H. S. Alrashdan, "Experimental Monitoring System Using Arduino Microcontroller in Studying The Effect of Temperature and Light Intensity of Solar Cell Output Power i n Ma ' an Development Area,"Int. Journal of Applied Engineering Research, vol. 14, no. 19, pp. 3770-3773, 2019.

[27] A. Rohmanu, "PemodelanAlat Monitoring Keseimbangan Arus Listrik Tiga Phasa Menggunakan Arduino dan SMS Gateway Dengan Berbasis Web Abstrak," Jurnal Informatika SIMANTIK, vol. 1, no. 1, pp. 26-31, 2016.

[28] S. Prasad, P. Mahalakshmi, A. J. C. Sunder, and R. Swathi, "Smart Surveillance Monitoring System Using Raspberry PI and PIR Sensor,"International Journal of Computer Science and Information Technologies (IJCSIT), vol. 5, no. 6, pp. 7107-7109, 2014.

[29] L. Ciabattoniet al., "Residential Energy Monitoring and Management Based on Fuzzy Logic,'IEEE International Conference on Consumer Electronics (ICCE), no. 2, pp. 536-539, 2015

[30] A. A. Kristi., et al.,"Perancangan Sistem Pendingin Photovoltaic dengan Memanfaatkan Kontroler Water Spray," ELKHA, J. Tek. Elektro, vol. 12, no. 2, pp. 47-53, 2020.

[31] F. Tampubolon, Y. Pratama., and I. G. E. Dirgayussa,
"Perancangan, Implementasi Monitoring dan Kontrol Alat Pemanggang Kopi," ELKHA, J. Tek. Elektro,vol. 12, no. 2, pp. 69-75, 2020.

[32] R. I. S. Pereira et al., "IoT Embedded Linux System based on Raspberry Pi applied to Real-Time Cloud Monitoring of a decentralized Photovoltaic plant," Measurement, pp. 1-18, 2017.

[33] Raspberrypi, "Teach, Learn, and Make with Raspberry Pi”, RaspberryPi, March 2021.

[34] L. O. Aghenta, "Development of an IoT Based Open Source SCADA System for PV System Monitoring," IEEE Can. Conf. Electr. Comput. Eng., pp. 1-4, 2019.

[35] K. Hentschel., et al,“ Supersensors: Raspberry Pi devices for smart campus infrastructure,"In 2016 IEEE 4th International Conference on Future Internet of Things and Cloud (FiCloud), pp. 58-62, 2016.

[36] P. A. Shinde., andY. B. Mane,"Advanced vehicle monitoring and tracking system based on Raspberry Pi,"In 2015 IEEE 9th International Conference on Intelligent Systems and Control (ISCO), pp. 1-6, 2015.

[37] S. Ferdoush., andX. Li, “ Wireless sensor network system design using Raspberry Pi and Arduino for environmental monitoring applications,"Procedia Computer Science, vol. 34, pp. 103-110, 2014.

[38] S. E. Oltean,“ Mobile Robot Platform with Arduino Uno and Raspberry Pi for Autonomous Navigation. Procedia Manufacturing,"vol. 32, pp. 572-577, 2019.

[39] R. Singh., et al,"Internet of Things with Raspberry Pi and Arduino," CRC Press, 2019.

[40] N. A. Othman, M. R. Zainodin, N. Anuar and N. S. Damanhuri, "Remote monitoring system development via Raspberry-Pi for small scale standalone PV plant," In 2017 IEEE 7th International Conference on Control System, Computing and Engineering (ICCSCE), pp. 360365,2017 